\title{
What do Iranian Undergraduate Students of Social vs. Natural Sciences Say about Their Language Needs?
}

\section{Razieh Gholaminejad ${ }^{1 *}$}

* Correspondence:

$\underline{\text { R_gholaminejad@sbu.ac.ir }}$

1. Department of English Language and Literature, Shahid Beheshti University,

Tehran, Iran

Received: 6 September 2019

Revision: 31 December 2019

Accepted: 24 January 2020

Published online: 20 March 2020

\begin{abstract}
Notwithstanding the obligation of courses such as English for Academic Purposes (EAP) in the Iranian university curriculum, exploring the language academic needs and abilities of students of social and natural sciences has been untouched. Focused on the students' perspectives, this study aims to identify the present and target situation academic language needs of Iranian undergraduate students of social vs. natural sciences in a comparative manner. A total of 260 undergraduate students studying natural sciences $(n=117)$ and social sciences $(n=143)$ at Sharif University of Technology and Shahid Beheshti University participated in this study by responding to a validated questionnaire on language needs self-assessment. Regarding the present language abilities, the natural sciences students considered themselves as much more competent in the English language compared to the social sciences students. However, the target language needs of both groups were roughly similar. Besides, both groups believed that the EAP courses should be oriented more towards English for Specific Purposes (ESP). Finally, while the majority of the natural sciences students asserted that the number of credits offered for the EAP courses was not enough, the comments made by the social sciences students were contrary. The paper concludes with a suggestion to revise the present program in order to boost the effectiveness of the EAP course and a discussion of implications for instructors and material designers.
\end{abstract}

Keywords: English as a foreign language, English for academic purposes, needs analysis, EAP, academic language needs 


\section{Introduction}

Since teaching the whole of a language is practically an implausible goal, English for Specific Purposes (ESP) emerged as a language teaching approach wherein all decisions with regard to content and method are derived from the students' reasons for language learning (Hutchinson \& Waters, 1987). ESP is founded on the premise that the students' target language situations contain classifiable components which should be incorporated into English for Academic Purposes (EAP) courses in order to satisfy the specific language needs of learners. On the other hand, Hyland's (2002) argument of the disciplinary specificity of English vocabulary augmented the reasoning behind the necessity of delivering specific English courses suitable for the particular group of learners. In this perspective, language curriculum design should begin with needs analysis (Savignon, 1997), without which all decisions concerning design, content, method, or practice would be intuitive and biased. Additionally, without needs analysis, a gap would be created between the students' and teacher's expectations as well as another gap between academic English programs and the realities of the students' future career (Atai \& Asadi, 2013). Not only through needs analysis such gaps could be bridged, but also a source could be created for developing tests which can be directly associated with real-world activities (Read, 2008).

According to Belcher (2006), ESP was a product of the learner-centered movement, by which language programs were assumed to be responsive to students' wants and desires. The aim was to give "learners a voice in content selection" (Belcher, 2006, p.139) and accordingly to empower them by making them participate in the decision making. As Helmer (2013) notes, the pivot of change is supposed to be in the language learner. In line with this viewpoint, "instructors do not always know with what tasks their students are struggling, and, importantly, why they are having difficulties" (Ferris, 1998, pp.292-293), as a result "the students themselves are the best sources of information on their own difficulties"' (p.312).

Eslami (2010) illustrated that students and teachers have different perceived problem areas in EAP classes, therefore teachers cannot always realize students' needs and problems (Eslami, 2010). In other words, subjective needs, which refer to the information provided by students themselves, should be an integral part of curriculum design (Brindley, 1989). Brown (2016) argues that in needs analysis the views and ideas of students are respected. In fact, teaching without considering the students' needs dehumanizes students (Freire, 1970), whereas taking such needs into consideration serves as an influential motivator for them. That is why Nunan (1993, p.4) recommends that "teachers should find out what their students think and feel about what they want to learn and how they want to learn." In needs analysis, the accuracy of the needs that students state is not an issue; what is important is gathering sufficient evidence for a reasonable curriculum (Peters \& Fernandez, 2013).

Needs analysts commonly employ a "present-to-target-situation needs analysis" (Helmer, 2013, p.275) in order to create an unambiguous image of the range of needs of the particular group of students. They attempt to include in surveys the potential language skills and sub-skills which students need at the present and in the future. To put it another way, needs-analysis surveys involve discovery of "what learners already know" (Dudley-Evans \& St John, 1998, p.124), which "tasks and activities learners are/will be using English for" (Dudley-Evans \& St John, 1998, p. 125 ), as well as "what the learner has to know in order to function effectively in the target situation" (Hutchinson \& Waters, 1987, p.55).

\subsection{Statement of the Problem}

In view of the importance of needs analysis in the EAP programs, and the lack of studies regarding the language needs of the undergraduate students of social and natural sciences in the context of Iran, the current study intended to deal with this shortage. The literature offers insufficient information concerning the difference between the perceptions of Iranian undergraduate students of social and natural sciences with respect to their present language abilities and future academic needs.

The rationale behind this comparison is the assumption that the nature of social sciences is fundamentally different from that of natural sciences. Besides, typically, the characteristics and abilities of students choosing to study these two types of disciplines are different from each other. As a result, it could be assumed that the present status and future language needs of the students of these disciplines are different too.

According to Soruç, Dinler, and Griffiths (2018), "Because of different needs of students in different majors, teachers should help them try certain strategies or different kinds of skill practice" (p.281). Besides, Hyland and Tse (2007) suggested that the EAP instruction needs to be discipline-specific. In the Iranian context, Noora (2008) investigated students' perspectives about English learning. He selected students majoring in Social Sciences, Business 
Management, Banking Management, Industrial Engineering, Chemistry, Physics, and Politics and found that students from different majors showed preferences for different language skills and teaching methods. He concluded that one should not assume that students from different disciplines can be treated with a similar standard approach, as different majors value different skills and teaching methods.

Moreover, the Iranian EAP policy makers generally issue equal and similar policies for all disciplines. The same number of credits is devoted to the EAP courses for different disciplines, while the needs, characteristics, and background of the students of these two types of disciplines may differ. Far more importantly, different disciplines may involve different academic or professional needs. The present study aims to develop a thorough comparative outline of the language needs of these two disciplines at the undergraduate level.

\subsection{Research Questions}

The following research questions were raised in this study:

1. What are the present academic English needs of Iranian undergraduate students of social vs. natural sciences?

2. What are the target academic English needs of Iranian undergraduate students of social vs. natural sciences?

3. Is there any significant difference between Iranian undergraduate students of social vs. natural sciences regarding their perceptions of their present and target academic English needs?

\subsection{Null Hypothesis}

In order to examine the third research question, the following null hypothesis was formulated:

H0: There is not any significant difference between Iranian undergraduate students of social vs. natural sciences regarding their perceptions of their present and target academic English needs.

\section{Review of the Related Literature}

Undergraduate programs of most disciplines at different institutions in Iran require students to pass a three-credit general English course, for which students attend classes for approximately four hours a week. The course is included in the curriculum for improving the students' general language proficiency, whereas in reality the only skills and language components that are covered are reading, vocabulary, grammar, and translation. Subsequently, undergraduate students are required to pass a two-to-four-credit EAP course, which normally deals with the disciplinespecific English. It aims "to bridge the gap between the learners' general English reading competence and their ability to read discipline-based texts" (Atai \& Tahririan, 2003, p.4). EAP is also included as a distinct section in the Iranian university entrance exam to postgraduate programs.

EAP instructors are typically supposed to choose the textbooks published by SAMT, which is the official center for developing university textbooks and materials for humanities and social sciences. Founded in the late 1970s (Atai, 2002a), this center aims to design structurally-uniform discipline-based EAP textbooks which are more closely focused on the students' language needs in each specific field of study. The general goal of EAP textbooks published by SAMT is to prepare students who can autonomously read different technical texts such as textbooks and articles (Atai, 2002a).

The hallmark of the EAP textbooks published by SAMT is the conspicuous prominence of reading texts related to each academic discipline, preceded by pre-reading and usually followed by exercises on reading comprehension skills and translation tasks as homework, or grammar and vocabulary exercises. All units are designed with consistent ingredients. The reading excerpts are chosen simply based on the relevance of the topic to each field of study (Mazdayasna \& Tahririan, 2008). At the level of practice, the courses are presented independently either by English language departments or by the corresponding subject departments with slight cooperation between the two centers (Atai, 2006; Atai \& Tahririan, 2003). In other words, EAP courses in Iran are taught by either content/subject-matter instructors or English-major instructors. While the former does not typically have sufficient knowledge of English language or the ability to teach it, the latter has insufficient technical knowledge. The instructors in each center employ different teaching methodologies. According to observations made by Atai (2002b), whereas subject-matter instructors simply employ sentence-by-sentence translation of the reading texts, the instructors from the English language department tend to use the technique of question-answer chains in teaching reading comprehension. 
Being based on the assumptions of the curriculum developers which are scientifically unconfirmed (Atai \& Nazari, 2011), the content of these textbooks are commonly compiled without prior systematic needs analysis (Atai, 2002a). In other words, they are designed without a clear examination of the academic or career language needs of students, their current background language knowledge, abilities, weaknesses, and desires. This is the consequence of the topdown trend in the Iranian EAP curriculum policy-making by which EAP policy makers issue policies to systematize EAP programs (Afshar \& Movassagh, 2016).

Atai and Tahririan (2003) examined the status of EAP instruction in Iran in a study conducted on a national scale, and found that EAP programs do not normally prepare the students to read and comprehend academic reading materials optimally. Asserting that undergraduate students are usually dissatisfied with the EAP programs in Iran, Atai and Shoja (2011, p.317) attributed the problems in the EAP curriculum to three causes: (1) learners' characteristics such as low motivation, and inadequate level of general English proficiency, (2) teachers' characteristics such as focus on language components (or teachers' methodology such as lack of teacher-student interactions, and unnecessary dependence on translation (Atai \& Tahririan, 2003), and (3) planning problems such as English-proficiency heterogeneity of the students in each classroom, and inadequate hours for each course.

Another study in the Iranian context was conducted by Vahdany and Gerivani (2016) who focused on the English language needs of medical students and general practitioners. The authors observed that for both medical students and general practitioners the reading skill was the most important language skill followed by writing, while speaking was considered as the least important. Another finding of the study was that general practitioners expressed more language needs than medical students.

Chao and Huang (2016) examined the English needs of Transportation Science students from the perspective of both teachers and students. Using questionnaires and interviews, they found that the English needs and wants of these students were different from their English lacks. In other words, the students lacked the skills related to ESP, while they needed and wanted to learn those related to General English. There was also an agreement between the instructors and students in that the students needed to improve general English proficiency, making general English courses more essential than ESP courses for students' success.

Kim and Joo (2018) conducted a survey to investigate the English needs of culinary students in Korea. They found that the students' perceived English need was correlated with the type of future career that they desired. Those students who planned to work for a restaurant or hotel abroad had the highest English proficiency needs whereas those planning to work in Korea had relatively lower language needs. The study concludes that the English programs should provide diverse language courses to prepare students for diverse future careers.

Kamaruddin, Izehari, and Sukimin (2017) investigated the language needs of Malaysian taxi drivers when communicating in English with their passengers. A case study design was employed in the study using interviews. They found that these drivers face three main challenges in communicating in English: First, the struggle to comprehend native speakers' speech; second, the difficulty in making and keeping conversations; and third, the difficulty in communicating with non-native speakers from non-English language speaking countries. The authors suggest that taxi companies consider offering English courses in order to improve the drivers' English proficiency.

Briana and Mutia (2018) conducted a language needs analysis on a sample of students of Information Technology, using quantitative and qualitative approaches. One of the findings of the study was that writing was considered by students as an important skill for their studies, whereas listening was considered by instructors as important for students' studies. However, speaking was considered as important by both groups for the students' future employment. The study concludes that contextualized language syllabi are needed to be created to fulfill the present and future English needs of these students.

Lu (2018) used a qualitative approach in order to examine the English needs and challenges of nurses as well as their perspectives on ESP courses offered to them. The participants worked in a hospital with an international care center in Taiwan. The study showed that the participants needed English communication skills to enable them build trusting nurse-patient relationships. Besides, they faced communication difficulties in the areas of vocabulary, pronunciation, and accent. The participants also considered their ESP courses ineffective, as they failed to meet their English needs. 


\section{Methodology}

\subsection{Design of the Study}

In the present study, a questionnaire was employed to collect the data; accordingly, measures of data collection were quantitative. In fact, a cross-sectional survey research method was used to explore the attitudes of two different groups of students towards their own language needs. Descriptive statistics were obtained to show different aspects of language needs in the participants. Here, there was an attempt to provide detailed descriptions of different language needs of the students of social and natural sciences in a comparative way. The variables of interest were the disciplines of students as the independent variable with two levels of social and natural sciences, and the dependent variable was the language needs. Here the design was Ex post facto, as we attempted to find a cause-effect relationship between discipline and language needs with no treatment or manipulation of variables involved in the study.

\subsection{Respondents and Setting}

The respondents involved in this study were 260 undergraduate students studying at Shahid Beheshti University and Sharif University (both of them located in Tehran, Iran). These universities are among the most remarkable state universities in Iran. Normally, the candidates with higher scores in national entrance exams are admitted in state universities in Iran. As a rule, Shahid Beheshti University and Sharif University run obligatory courses of general English and EAP. Usually general English courses are taught by teachers from the English department, whereas EAP courses are taught by subject-matter teachers from the related department. In both courses, the medium of instruction is generally Farsi (the official language in Iran).

\subsection{Materials}

In order to examine the present and target language needs of undergraduate students, a validated questionnaire developed by Atai and Shoja (2011) was used by permission. The content of the questionnaire comprised three main sections: (1) background, (2) present language abilities, and (3) target language needs. The first part of the questionnaire dealt with the demographic background of the respondents.

The second part, which consisted of 20 items on a four-Likert scale, inquired how important each of the listed language skills or components were for the participants' academic success. In fact, this part measured the target situation language needs of students. To further explore the target needs, another question was included which asked whether the number of credits devoted to EAP courses at the undergraduate level was adequate or not. Besides, the participants were asked whether the EAP courses should be oriented more towards general English or ESP.

The third part, which consisted of 32 items on a four-Likert scale, elicited the students' self-assessment of their present language abilities (English language proficiency). Here the respondents were asked to identify the extent to which they could do the listed language skills and components. To clarify further a reflection of the respondents' present abilities, they were also asked to rank their own general English proficiency level from weakest to strongest in terms of the six-band scale of the Common European Framework of Reference (CEFR) described by the Council of Europe.

\subsection{Procedure of the Study}

Selection of participants was made through convenience sampling, which is a non-probability sampling technique wherein the samples are chosen if they are easily available in terms of certain time or geographical proximity (Dörnyei \& Csizér, 2012). Our sampling was not, of course, entirely accessibility-based; rather, we also required that the sample featured specific characteristics. The respondents were restricted to the undergraduates studying one of the disciplines classified as social or natural sciences. Physics, geology, chemistry, and biology were selected to represent the natural sciences, while administration, economics, and psychology stood for social sciences. This selection was made based on the availability of students. The study was conducted in the departments related to each discipline.

\subsection{Data Collection}

A single phase of data collection was included, which involved the administration of the questionnaire developed by Atai and Shoja (2011). The questionnaire was the only source of data collection, which focused on gathering the data related to the participants' background, present language abilities, and target language needs. The survey questionnaire was distributed in classrooms and participants voluntarily took part. The respondents were allocated sufficient time to fill in the questionnaire. The respondents were also ensured about the confidentiality. Of the total participants, 73 
percent were female and 27 percent were male. This proportion imbalance is inevitably expected as nowadays the majority of undergraduate candidates in Iranian universities (especially for the social sciences) are women.

\subsection{Data Analysis}

The results of the questionnaire were analyzed through descriptive and inferential statistics including the independent samples t-test, using the Statistical Package for Social Sciences (SPSS). In order to answer the third research question, independent samples t-tests were used in order to find out whether the social and natural sciences students had significantly different perceptions of their present and target needs.

\section{Results}

\subsection{Present-Situation Academic Language Needs}

The first research question explored the present academic language needs of the participants. A descriptive analysis of the self-assessment data regarding the present level of language abilities of the participants revealed that social sciences students perceived their ability as weak in many of the skills compared to natural sciences students. More specifically, social sciences students considered themselves as weak in "Reading and comprehending subject specific texts in English" (61.5\%), "Critical reading" (69.9\%), "Writing summary of subject specific texts" (68.5\%), "Preparing English slides" (65.7\%), "Writing scientific articles" (80.4\%), "Writing homework and assignments an English" (74.1\%), "Taking class examinations in English" (69.2\%), "Comprehending English lectures" (73.4), "Participating in international events" (74.8\%), "Note-taking from lectures related to the field" (66.4\%), "Translating technical texts (from Persian to English)" (69.2\%), and "Knowledge of technical vocabulary" (62.2\%). However, natural sciences students perceived themselves as incapable only in "Writing scientific articles" (71.8\%) and "Notetaking from lectures related to the field" $(60.7 \%)$.

Another research question examined whether there were any significant differences between the students of social vs. natural sciences regarding their perceptions of their present and target academic English needs. Regarding their present language needs, the null hypothesis was that there are no significant differences between the two groups' present language needs. To explore if the gap between the present language skills of social vs. natural sciences students was statistically significant, an independent samples t-test was run. According to Table 1, there is a significant difference between the present level of social and natural sciences students $(t=5.97, \mathrm{df}=258, \mathrm{p}<0.05)$. Therefore, the null hypothesis is rejected. That is, natural sciences students perceived themselves as much more competent in English language related skills compared to the students majoring in social sciences who deemed themselves to be weak in many of the skills.

Table 1. Independent samples t-test

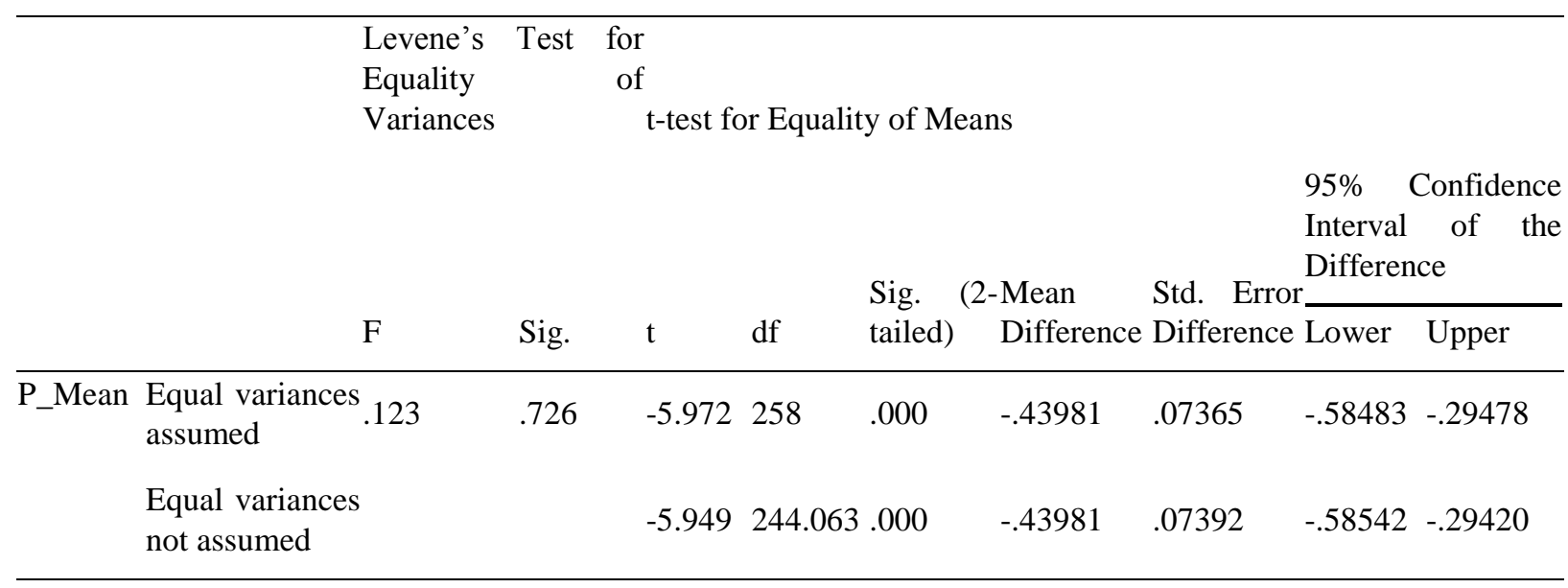

The present language abilities of the students were also examined by asking them to rate themselves in terms of the CEFR bands. As illustrated in Table 2, the majority of students majoring in social sciences assessed their levels as the 
lowest on the scale, i.e. A1 and A2 (21.7\% \& 46.9\%, respectively). Levels B1 and B2 were selected by $26.6 \%$ and $4.2 \%$ of natural sciences students, respectively. Finally, only $0.7 \%$ of them deemed their proficiency level as C1. No one chose $\mathrm{C} 2$ in social sciences. On the other hand, approximately one-third of the natural sciences students selected A1 (3.4\%) and A2 (27.4\%). The intermediate levels, i.e. B1 and B2, were chosen by more than half of the students majoring in natural sciences $(45.3 \% \& 12.0 \%$, respectively). At last, $10.3 \%$ perceived their levels as $\mathrm{C} 1$, and $1.7 \%$ decided that they were at the $\mathrm{C} 2$ level.

Table 2. Participants' levels based on CEFR bands

\begin{tabular}{lllllll}
\hline Discipline & A1 & A2 & B1 & B2 & C1 & C2 \\
\hline Social Sciences & 31 & 67 & 38 & 6 & 1 & 0 \\
$(\mathrm{n}=143)$ & $21.7 \%$ & $46.9 \%$ & $26.6 \%$ & $4.2 \%$ & $0.7 \%$ & $0 \%$ \\
\hline Natural Sciences & 4 & 32 & 53 & 14 & 12 & 2 \\
$(\mathrm{n}=117)$ & $3.4 \%$ & $27.4 \%$ & $45.3 \%$ & $12.0 \%$ & $10.3 \%$ & $1.7 \%$ \\
\hline
\end{tabular}

\subsection{Target-Situation Academic Language Needs}

Another research question investigated the target academic English needs of Iranian undergraduate students of social vs. natural sciences. To this end, the participants responded to the items related to the essential language skills, subskills, and components that could facilitate their future academic studies. The descriptive analysis of the data with respect to the target needs of the two groups of students indicated that the social sciences students deemed "Reading subject specific texts in English" (71.3\%), "Comprehending English lectures" (75.5\%), "Using Internet to do research" $(82.5 \%)$, "Knowledge of general vocabulary" (88.1\%), and "Knowledge of technical vocabulary" (83.9\%) to be important for their academic success. As for the natural sciences students, on the other hand, "Reading subject specific texts in English" (86.3\%), "Understanding teachers' slides in English" (77.8\%), "Writing scientific articles" (81.2\%), "Comprehending English lectures" (91.5\%), "Participating in international events" (76.1\%), "Using Internet to do research" (89.7\%), "Knowledge of general vocabulary" (76.1\%), "Knowledge of technical vocabulary" (92.3\%), "Translating technical texts (from English to Persian)" (76.9\%), and "Writing e-mails to teachers and field experts" $(72.6 \%)$ were paramount in terms of future academic needs.

The other part of the third research question asked if there were any significant differences between the students of social vs. natural sciences regarding their perceptions of their target academic English needs. The null hypothesis was that there were no significant differences between the two groups regarding their perceptions of their target academic English needs. Again an independent samples t-test was used in order to find out whether the social and natural sciences students had significantly different perceptions of their target needs. As shown in Table 3, the perceptions of the social and natural sciences university students with respect to their target needs were more or less similar $(\mathrm{t}=0.86$, $\mathrm{df}=258, \mathrm{p}>0.05)$. Thus, the null hypothesis could not be rejected. That is, the differences between the students of social vs. natural sciences regarding their perceptions of their target academic English needs were not significant. 
Table 3. Independent samples t-test

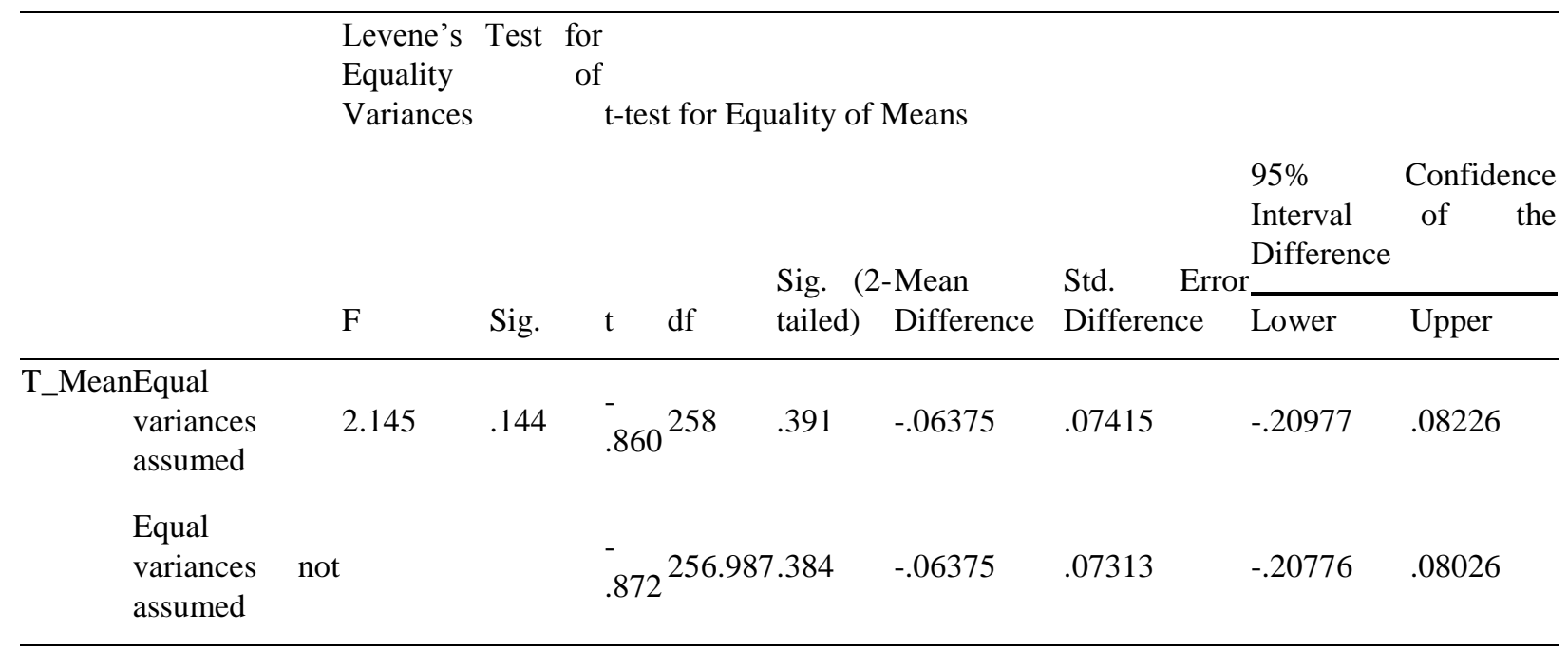

Another aspect of the students' target academic language needs focused on asking the participants if they preferred that EAP classes be oriented towards ESP or general English. The students of social and natural sciences alike (69.9\% \& $71.8 \%$, respectively) believed that EAP courses should be oriented more towards ESP (Table 4).

Table 4. Orientation of ESP classes

\begin{tabular}{lll}
\hline Discipline & General English & English for Specific Purposes \\
\hline Social Sciences & 43 & 100 \\
$(\mathrm{n}=143)$ & $30.1 \%$ & $69.9 \%$ \\
\hline Natural Sciences & 33 & 84 \\
$(\mathrm{n}=117)$ & $28.2 \%$ & $71.8 \%$ \\
\hline
\end{tabular}

Also related to the students' target academic language needs was the issue of the participants' viewpoints regarding the sufficiency of the number of credits for the ESP course. The results showed that almost half of the social sciences students $(49.0 \%)$ believed that the number of credits offered for the ESP course was enough (Table 5). However, the other half $(51.0 \%)$ perceived the amount of time devoted to the EAP to be insufficient. On the other hand, as for the natural sciences students, only 30 were of the opinion that the amount of time spent on EAP was sufficient, and the majority $(74.4 \%)$ decided that was not enough at all.

Table 5. Sufficiency of the amount of EAP instruction

\begin{tabular}{lll}
\hline Discipline & Adequate & NOT adequate \\
\hline Social Sciences & 70 & 73 \\
$(\mathrm{n}=143)$ & $49.0 \%$ & $51.0 \%$ \\
\hline Natural Sciences & 30 & 87 \\
$(\mathrm{n}=117)$ & $25.6 \%$ & $74.4 \%$
\end{tabular}




\section{Discussion}

The present study was a comparative attempt to investigate the present and target language needs of Iranian undergraduate students of social vs. natural sciences. As for the question dealing with the present academic English needs of the students, the majority of social sciences students reported problems with a number of sub-skills of 'reading,' 'writing,' 'speaking,' 'listening,' 'translation,' and 'technical vocabulary.' However, only the sub-skills related to 'writing' and 'listening' were reported by the majority of the natural sciences students as problematic areas. In other words, whereas the majority of natural sciences students perceived themselves weak in only two skills, the social sciences students added ten other skills with which they had problems.

Although the two groups of participants in the present study expressed different present language needs, Vahdany and Gerivani (2016) found that for both of the groups of participants in their study the reading skill was the most important language skill followed by writing. The difference observed in the present study may be attributed to the difference in the nature of social vs. natural sciences and the dissimilar characteristics of the typical applicants of these two programs. Similarly, Briana and Mutia (2018) found that different language skills were considered as important by different groups of stakeholders.

Another research question sought to find any significant differences between the students of social vs. natural sciences regarding their perceptions of their present academic English needs._With a statistically significant difference, the natural sciences students perceived themselves as much more competent in the English language compared to the social sciences students. This lower level of the present abilities was also confirmed when the students commented on their abilities in terms of the CEFR bands. In fact, whilst the majority of social sciences students assessed their levels as the lowest on the scale (A), the majority of the natural sciences students perceived their current abilities in agreement with a level higher (B).

Atai and Shoja (2011) in a similar needs-analysis study of computer engineering undergraduates found that the participants assessed themselves at the three weaker levels of CEFR (i.e. A1, A2, \& B1). Thus, it seems to have an agreement with the present study in that the participants perceived their own levels on almost similar CEFR bands. Overall, the low CEFR bands (A and B) selected by the majority of the participants as well as the numerous problematic areas selected can reveal the inadequate English proficiency of the Iranian undergraduate students. This low English proficiency of students was also reported by Evans and Green (2007) in the context of Hong Kong. This is also supported by Atai and Shoja (2011) who argued that the level of students' English proficiency can affect the orientation of the EAP courses. Similar findings were achieved by Atai and Tahririan (2003) and Atai (2002) who distrusted if university students in Iran ever internalized the essential academic skills.

Concerning the research question which investigated the target language needs, five skills were selected by the majority of social sciences students as important language skills, while ten skills were mentioned by the natural sciences participants as important for their future academic success. Kim and Joo (2018), with similar findings, concluded that the English programs should provide diverse language courses to prepare students for diverse future needs. This is in line with Soruç, et al. (2018) who argued that as needs of students in different majors differ, teachers teach certain strategies or use different methodologies or skill practice.

As for the research question which examined any significant differences between the students of social vs. natural sciences regarding their perceptions of their target academic English needs, it was found that the target needs of both groups were statistically similar. The similarity of the target language needs for students majoring in disciplines with sharply different nature is in line with the findings from class observations made by other researchers (Atai \& Nazari, 2011; Atai \& Shoja, 2011) who observed no systematic emphasis in EAP classes on discipline-specific skills and subskills which are typically required by the demands of subject specific EAP courses. This could suggest that since EAP courses are taught similarly for different disciplines, perceptions of the students regarding their target needs turn out to be alike.

Moreover, the majority of both groups believed that EAP courses should be oriented more towards ESP rather than general English. This is compatible with the results obtained by Atai and Shoja (2011) whose participants commented likewise. This is, however, in disagreement with the participants' comments in a similar study conducted by Chao and Huang (2016) who found that the students needed to improve general English proficiency, which made general English courses more essential than ESP courses for students' success. 
Finally, almost half of the social sciences students believed that the number of credits for the EAP course was enough. However, the majority of the natural sciences students asserted that the number of credits was not enough-a finding which is compatible with the participants' ideas in the study conducted by Atai and Shoja (2011). The finding that half of the social sciences students supposed that the number of credits for the EAP course was enough for them may be attributed to the lower level of their proficiency. In fact, being weak in English demotivated them to take more English courses.

Our findings regarding the statistically significant effect of discipline on the students' perception of their present language needs as well as the contrasting comments of the participants in the two groups regarding the sufficiency of the time allocated for the EAP course may go in line with the findings obtained by Hyland and Tse (2007) who argued for the specificity of the EAP instruction for each discipline.

\section{Concluding Remarks and Implications}

This study reveals that the present and target language needs of different disciplines may not be similar. Furthermore, the content and number of credits devoted to EAP courses for different disciplines do not need to be equal for all disciplines and should match the type of discipline. Thus, the EAP policies issued for different disciplines need to be renewed to match the typical students' proficiency level and the target needs for each discipline. They should be designed separately based on the specific needs of the particular group if we wish them to improve optimally. Serving as a referential database for the language needs of Iranian undergraduate students of social and natural sciences, the results of the present study can be useful for the students of these disciplines by informing them of the types of skills or sub-skills required by other students studying similar disciplines.

Furthermore, the findings of the present study bear implications for EAP instructors. It could give them insights about the significance of running needs analysis before beginning each program. Instead of using pre-specified materials, instructors need to tailor the content of the course based on the specific group, and refresh their teaching methodology based on them. Besides, EAP instructors need to pay more attention to the skills and sub-skills reported as problematic by students of each discipline. They need to include in the EAP syllabus other skills apart from the reading comprehension and preferably make use of textbooks which improve the four main language skills altogether.

Finally, finding that the students' CEFR levels, especially of the students of social sciences, were low should inspire the syllabus designers, policy makers or program designers to make more realistic decisions in designing EAP programs or in developing language courses. Iranian policy makers and curriculum designers need to add supplementary remedial English proficiency courses for students of certain disciplines such as social sciences.

\section{References}

Afshar, H. S., \& Movassagh, H. (2016). EAP education in Iran: Where does the problem lie? Where are we heading? Journal of English for Academic Purposes, 22, 132-151. https://doi.org/10.1016/j.jeap.2016.04.002

Atai, M. R. (2002a). EAP curriculum development in Iran: An incoherent educational experience. Special Issue of the Journal of Faculty of Letters and Humanities, Teacher Training University, 9(33), 17-34. https://www.sid.ir/en/journal/ViewPaper.aspx?id=22446

Atai, M. R. (2002b). Iranian EAP programs in practice: A study of key methodological aspects. Sheikhbahaee Research Bulletin, 1(2), 1-15.

Atai, M. R. (2006). EAP teacher education: Searching for an effective model integrating content and language teachers' schemes. Proceedings of PAAL conference. Kangwong National University, Chuncheon, Korea. http://www.paaljapan.org/resources/proceedings/PAAL11/pdfs/03.pdf

Atai, M. R., \& Asadi, S. A. (2013). Assessing academic and professional English language needs of Iranian railway engineering students: A triangulated evaluation study. ESP across Cultures, 10, 35-54. https://edipuglia.it/wpcontent/uploads/ESP\%202013/Mahmood-Reza-Atai-Seyyed-Asadollah-Asadi.pdf

Atai, M. R., \& Nazari, O. (2011). Exploring reading comprehension needs of Iranian EAP students of health information management (HIM): A triangulated approach. System, 39(1), 30-43. https://doi.org/10.1016/j.system.2011.01.015 
Atai, M. R., \& Shoja, L. (2011). A triangulated study of academic language needs of Iranian students of computer engineering: Are the courses on track? RELC Journal, 42(3), 305-323. https://doi.org/10.1177/0033688211419392

Atai, M. R., \& Tahririan, M. H. (2003). Assessment of the status of ESP in the current Iranian higher educational system. Proceedings of LSP: Communication, culture and knowledge conference. Guilford, England: University of Surrey.

Belcher, D. (2006). English for specific purposes: teaching to perceived needs and imagined futures in worlds of work, study, and everyday life. TESOL Quarterly, 4O(1), 133-156. https://doi.org/10.2307/40264514

Briana, J. C. D., \& Mutia, M. L. D. (2018). An English language needs analysis of information technology students. Paper presented at Linguistic Society of the Philippines National Conference and General Meeting. doi: $\underline{10.13140 / R G .2 .2 .11292 .13449}$

Brindley, G. P. (1989). The role of needs analysis in adult ESL program design. In R. K. Johnson (ed.), The second language curriculum (pp. 63-78). Cambridge: Cambridge University Press. https://doi.org/10.1017/CBO9781139524520.007

Brown, J. D. (2016). Introducing needs analysis and English for specific purposes. (Routledge Introductions to English for Specific Purposes) 1st Edition. https://www.amazon.com/Introducing-Analysis-SpecificRoutledge-Introductions/dp/1138803812

Chao, W., \& Huang, J. C. (2016). ESP vs. EGP: Investigating English needs of University students in transportation science. English for Specific Purposes World, 17(49), 1-15. http://esp-world.info/Articles 49/Chao Huang.pdf

Dörnyei, Z., \& Csizer, K. (2012). How to design and analyze surveys in second language acquisition research. In A. MacKey \&S. M. Gass (Eds.), Research methods in second language acquisition: A practical guide (pp. 74-94). West Sussex: Blackwell.

Dudley-Evans, T., St John, M. J., \& Saint John, M. J. (1998). Developments in English for specific purposes: A multidisciplinary approach. Cambridge University https://www.cambridge.org/bs/cambridgeenglish/catalog/teacher-training-development-andresearch/developments-english-specific-purposes/developments-english-specific-purposes-a-multidisciplinary-approach-paperback

Eslami Rasekh, Z. (2010). Teachers' voice vs. students' voice: A needs analysis approach to English for Academic Purposes (EAP) in Iran. English Language Teaching, 3(1), 3-11. https://doi.org/10.5539/elt.v3n1p3

Evans, S., \& Green, C. (2007). Why EAP is necessary: A survey of Hong Kong tertiary students. Journal of English for Academic Purposes, 6(1), 3-17. doi: 10.1016/j.jeap.2006.11.005

Ferris, D. (1998). Students' views of academic aural/oral skills: A comparative needs analysis. TESOL Quarterly, 32(2), 289-318. https://doi.org/10.2307/3587585

Freire, P. (1970). Pedagogy of the oppressed. New York: Continuum.

Helmer, K. A. (2013). A twice-told tale: Voices of resistance in a borderlands Spanish heritage language class. Anthropology \& Education Quarterly, 44(3), 269-285. https://doi.org/10.1111/aeq.12025

Hutchinson, T., \& Waters, A. (1987). English for specific purposes: A learning centered approach. Cambridge: Cambridge University Press. https://doi.org/10.1017/CBO9780511733031

Hyland, K., \& Tse, P. (2007). Is there an "academic vocabulary"? TESOL quarterly, 41(2), 235-253. https://doi.org/10.1002/j.1545-7249.2007.tb00058.x

Kamaruddin, S. N. D. M., Izehari, Z. F., \& Sukimin, I. S. (2017). Language needs analysis: An initial investigation on Malaysian drivers for alternative taxi company. Asian Journal of Social Science Studies, 2(4), 4553. https://doi.org/10.20849/ajsss.v2i4.239 
Kim, K., \& Joo, K. (2018). Korean culinary college students' desired careers and English proficiency needs. English Teaching, 73(1), 161-181. https://vdocuments.mx/document/korean-culinary-college-studentsa-desiredcareers-and-english-proficiency-2018-04-11.html

Lu, Y. L. (2018). What do nurses say about their English language needs for patient care and their ESP coursework: The case of Taiwanese nurses. English for Specific Purposes, 50, 116129. https://doi.org/10.1016/j.esp.2017.12.004

Mazdayasna, G., \& Tahririan, M. H. (2008). Developing a profile of the ESP needs of Iranian students: The case of students of nursing and midwifery. Journal of English for Academic purposes, 7(4), 277-289. https://doi.org/10.1016/j.jeap.2008.10.008

Noora, A. (2008). Iranian undergraduates non-English majors' language learning preferences. GEMA Online ${ }^{\circledR}$ Journal of Language Studies, 8(2), 33-44. http://ejournals.ukm.my/gema/article/view/171

Nunan, D. (1993). From learning-centeredness to learner-centeredness. Applied Language Learning, 4(1), 1-18. https://eric.ed.gov/?id=EJ477796

Peters, P., \& Fernández, T. (2013). The lexical needs of ESP students in a professional field. English for Specific Purposes, 32(4), 236-247. https://doi.org/10.1016/j.esp.2013.05.002

Read, J. (2008). Identifying academic language needs through diagnostic assessment. Journal of English for Academic Purposes, 7(3), 180-190. https://doi.org/10.1016/j.jeap.2008.02.001

Savignon, S. J. (1997). Communicative competence: Theory and classroom practice: Texts and contexts in second language learning. McGraw-Hill Humanities Social.

Soruç, A., Dinler, A., \& Griffiths, C. (2018). Listening comprehension strategies of EMI students in Turkey. In Key issues in English for specific purposes in higher education (pp. 265-287). Springer, Cham. https://www.amazon.com/English-Specific-Purposes-Education-Language/dp/3319702130

Vahdany, F., \& Gerivani, L. (2016). An analysis of the English language needs of medical students and general practitioners: A case study of Guilan University of Medical Sciences. International Journal of English Language and Literature Studies, 5(2), 104-110. https://doi.org/10.18488/journal.23/2016.5.2/23.2.104.110 